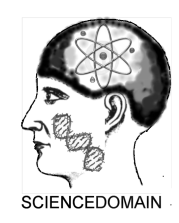

\title{
Effect of Planting Date and Boll Position on Fiber Strength of Cotton (Gossypium hirsutum L.)
}

\author{
Zhiguo Zhou ${ }^{1}$, Yali Meng ${ }^{1}$, Youhua Wang ${ }^{1}$, Binglin Chen ${ }^{1}$, \\ Xinhua Zhao ${ }^{2}$, Derrick M. Oosterhuis ${ }^{3^{*}}$ and Hongmei Shu ${ }^{4}$ \\ ${ }^{1}$ Key Laboratory of Crop Physiology and Ecology, Southern China of Ministry of Agriculture, \\ Nanjing Agricultural University, Nanjing 210095, Jiangsu Province, P. R. China. \\ ${ }^{2}$ Cotton Research Institute, Chinese Academy of Agricultural Sciences, Anyang 455004, \\ Henan Province, P. R. China. \\ ${ }^{3}$ Department of Crop, Soil, and Environmental Sciences, University of Arkansas, \\ Fayetteville, AR. 72704, USA. \\ ${ }^{4}$ Institute of Agro-biotechnology, Jiangsu Academy of Agricultural Sciences, Nanjing 210014, \\ Jiangsu Province, P. R. China.
}

Research Article

Received $21^{\text {st }}$ July 2011

Accepted $21^{\text {st }}$ August 2011

Online Ready $7^{\text {th }}$ September 2011

\section{ABSTRACT}

The effect of planting date and boll position on cell wall thickening of cotton fiber and development of fiber strength were studied by comparing the time course of the activity of key enzymes $\beta$-1,3-glucan synthase (callose) and sucrose synthase (SuSy) involved in cellulose biosynthesis, cellulose content and the indices of fiber structure X-ray diffraction of the fiber that developed at different planting dates or boll positions. The results showed that during the fiber cell wall thickening and fiber strength formation stage (25-50 days post-anthesis, DPA), there was an interactive effect between planting date and boll position. Different planting dates resulted in different mean daily temperatures during 2550 DPA ( $\left.T_{D P A} 25-50\right)$, which was always an important factor that influenced fiber strength, while the impact of boll position in different temperature conditions was variable. When $\mathrm{T}_{\mathrm{DPA} 25-50}$ was above $22.0^{\circ} \mathrm{C}$, boll position might affect the cell wall thickening process and the fiber strength, while when $T_{\text {DPA25-50 }}$ was lower than $20.0^{\circ} \mathrm{C}$, boll position affect little. The optimum conditions for the development of fiber cell wall thickening and the formation of fiber strength may be the eighth nodal position of the fruiting branch (PFB) and with the $\mathrm{T}_{\text {DPA } 25-50}$ of about $26.0^{\circ} \mathrm{C}$. 
Keywords: Cotton; fiber quality; sucrose synthase; $\beta$-1,3-glucan synthase; planting date; boll position; temperature;

\section{ABBREVIATIONS}

DPA: Days Post Anthesis; FBP: Fruiting Branch Position; the rank of the fruiting branch on the main stem from bottom to top;

\section{INTRODUCTION}

Cotton fiber is an important raw material for the textile industry (Macdonald and Vollrath, 2005), and fiber strength is one of the most important criteria for spinning value as it determines yarn strength (Meredith, 2005). Cotton fibers originate from the outer seed coat of developing seed and their development occurs in four distinct phases including primary wall deposition, elongation, secondary wall thickening or maturation and then drying (Kim and Triplett, 2001; Davidonis et al., 2004). During the secondary wall deposition stage, 25-50 days post anthesis (DPA), fiber cells mainly undergo cellulose biosynthesis, and fiber strength is closely related to the cellulose synthesis process (Wang et al., 2009), so this stage is the key period determining fiber strength (Kim and Triplett, 2001).

The quality of the secondary wall depends primarily on the characteristics of cellulose accumulation, while cellulose biosynthesis is mainly affected or controlled by the dynamic changes and correlative functions of the key enzymes activity (Saxena and Brown, 2000; Williamson et al., 2002). It is generally accepted that sucrose synthase (SuSy, EC 2.4.1.13) and $\beta$-1,3-glucan synthase (callose synthase, EC 2.4.1.34) are two predominant enzymes involved in cellulose biosynthesis (Brown et al., 1996; Ruan et al., 1997). Research has shown that SuSy plays an important role in cellulose accumulation (Amor et al., 1995; Ruan and Churey, 1998; Delmer and Haigler, 2002). In fact, SuSy (sucrose + UDP ↔UDP-glucose + fructose) could degrade sucrose to provide carbon for respiration and synthesis of cell wall polysaccharides. In non-photosynthetic tissues, high levels of SuSy activity and steady-state measurement of its substrate and product levels showed that the SuSy catalysis functions primarily in terms of sucrose degradation and UDP-glucose synthesis (Amor et al., 1995). In cotton fiber, for example, a membrane -associated form of SuSy serves to channel carbon directly from sucrose to cellulose synthase in the plasma membrane (Amor et al., 1995; Haigler et al., 2001; Salnikov et al., 2003). Additionally, Ruan et al. (2003) showed that highcellulose fibers could not develop if sucrose synthase activity has been significantly decreased.

The cell wall of cotton fibers also contains substantial quantities of $\beta$-1,3-glucan (callose) at the time of secondary wall cellulose synthesis (Scheible and Pauly, 2004). In fact, callose is similar to cellulose in structure, and both polymers are synthesized with UDP-glucose as the substrate. Normally, callose accumulation is jointly controlled by $\beta-1,3-$ glucanase and $\beta-1,3-$ glucan synthase (callose synthase), which degrade and synthesize callose, respectively (Delmer, 1999). Although callose synthase and cellulose synthase use the same substrate UDP-glucose, they synthesize different products. So a dynamic change in callose synthase activity would have an effect on cellulose synthesis during the secondary wall thickening. 
Fiber quality is not only determined by cellulose accumulation but also determined by morphological and structural properties of fibers. Microfibrils distribution and orientation are strongly related to fiber strength, and changes are usually reflected in variations of fiber traits (Liu et al., 1996). X-ray diffraction studies showed that the fiber structure character could be presented by three angles: orientational separate angle $(\alpha)$, spiral angle $(\varphi)$ and orientational distribution angle $(\psi)$. Orientational separate angle $(\alpha)$ was defined as the tropism of the cellulose crystal granule in the spiral structure of the fiber in the secondary cell wall (Liu et al., 1996). Spiral angle stands for the angles that the cellulose polymers separate from the longitudinal axis of the fiber (Liu et al., 1996). The smaller the angles, the more orderly the microfibrils were laid down and the higher the strength of the fiber (Liu et al., 1996; Zhao et al., 2005).

Planting date is one of the most important management factors which affect cotton development (Ali et al., 2009). Wang et al. (2008) suggested that low temperature in late sowing dates resulted in a decrease in cotton fiber strength by the down-regulation of cellulose accumulation rate and key enzymes activities. Hence, it is relevant to assess whether the differences both in the transformation of the major substances, and in the activities of the above key enzymes during the secondary wall thickening, could affect cellulose deposition and even fiber strength. However, little work has been carried out in this field.

On the other hand, cotton fiber quality has a close association with the position of the fruiting branch (PFB), but whether boll position has significant effects on the developing process of cotton fiber strength is still uncertain. Sequeira et al. (1994) suggested that cotton fiber strength was affected by nodal position, while Bernhardt and Phillips (1986) noted that boll location had a significant influence on lint weight and micronaire but not on fiber length and strength. So a clear understanding of how and to what degree does fiber strength relate to boll position is very important for developing appropriate cultivation methods to maintain or even increase fiber strength.

In the present study, experiments were conducted determining the spatial and temporal changes of the key enzyme activity involved in cellulose biosynthesis, cellulose content and the indices of fiber structure X-ray diffraction of the fiber that developed in different planting dates or boll positions. The objective was to determine whether they are involved in the development of cotton fiber strength.

\section{MATERIALS AND METHODS}

\subsection{Experimental Design}

Field experiments were carried out at Jiangsu Academy of Agricultural Sciences, Nanjing, Jiangsu province, China $\left(118^{\circ} 50^{\prime} \mathrm{E}, 32^{\circ} 02^{\prime} \mathrm{N}\right)$ in 2002 and 2003 . Soil of the experimental site was a yellow-brown loam (Dystrudept) with $2.5 \%$ organic matter, $12.0 \mathrm{~g} \mathrm{~kg}^{-1}$ total nitrogen $(\mathrm{N}), 85.1 \%$ available $\mathrm{N}, 13.0 \mathrm{mg} \mathrm{kg}^{-1}$ available phosphorus $(\mathrm{P})$ and $91.6 \mathrm{mg} \mathrm{kg}^{-1}$ available potassium (K) in the upper $20 \mathrm{~cm}$ soil layer. We applied a contrast design with three replicates, and planting date was the factor. Irrigation and fertilization were applied according to the local recommend methods for high yield and high quality fiber production. 
In the two-year experiment, cotton (Gossypium hirsutum L.) cultivar DPL NuCOTN ${ }^{33 \mathrm{~B}}$ was sown on 20 April (I) and 20 June (II). Each plot contained ten rows of cotton with a row spacing of $0.90 \mathrm{~m}$, an interplant space of $0.40 \mathrm{~m}$, with 3 replications.

\subsection{Sampling and Weather Data}

Bolls set at the first node in all plants were labeled on the day of flowering, the bolls in the $8^{\text {th }}$ and $12^{\text {th }}$ PFB of the plants which were sown on 20 April were labeled as I-8 and I-12, respectively, and bolls set on the $2^{\text {th }}, 8^{\text {th }}$ and $12^{\text {th }}$ PFB of the plants sown on 20 June were labeled as II-2, II-8 and II-12, respectively. In the experiment, I-12 and II-2 were labeled at the same time. Ten labeled bolls from each treatment and replication were collected every 5 days from 25 DPA to 50 DPA. Cotton fibers and seeds were excised from the bolls with a scalpel and the detached fibers (without seeds) were rapidly placed into liquid nitrogen for subsequent measurements.

The weather data was provided by the Nanjing Weather Bureau. Mean daily temperatures during 25-50 DPA (TPA25-50) for each boll in the two years of the study is presented in Table 1.

Table 1. $T_{\mathrm{DPA} 25-50}$ of different treatments in 2002 and 2003

\begin{tabular}{cccccc}
\hline \multirow{2}{*}{ Year } & \multicolumn{5}{c}{$\mathbf{T}_{\text {DPA25-50 }}\left({ }^{\circ} \mathrm{C}\right)$} \\
\cline { 2 - 6 } & $\mathbf{I - 8}^{*}$ & $\mathbf{I}-12$ & II-2 & II-8 & II-12 \\
\hline 2002 & 26.0 & 22.0 & 22.0 & 19.6 & 16.4 \\
2003 & 26.2 & 19.4 & 19.4 & 16.0 & 15.8 \\
\hline
\end{tabular}

* $I-8$ and I-12 stands for the $8^{\text {th }}$ and $12^{\text {th }}$ PFB in the planting date of 20 April, respectively; II-2, II-8 and $11-12$ stands for the $2^{\text {th }}, 8^{\text {th }}$ and $12^{\text {th }}$ PFB in the planting date of 20 June, respectively.

\subsection{Determination of the $\beta-1,3-$ Glucan Synthase Activity}

The fibers $(0.5 \mathrm{~g} \mathrm{FW})$ were homogenized in a glass Potter homogenizer at $0^{\circ} \mathrm{C}$ in $5 \mathrm{ml} 100$ $\mathrm{mM} \mathrm{Tes} / \mathrm{NaOH}$ ( $\mathrm{pH} 7.0$ ) buffer, and then centrifuged for $3 \mathrm{~min}$ at $480 \mathrm{~g}$ and the supernatant was used in the enzyme assay. $50 \mu \mathrm{l}$ enzyme preparations were mixed with $50 \mu \mathrm{l}$ assay buffer containing $50 \mathrm{mM}$ Tes/NaOH (pH 7.0), $20 \mathrm{mM}$ cellobiose, $16 \%(\mathrm{w} / \mathrm{v})$ glycerol, $10 \mathrm{mM}$ $\mathrm{MgCl}_{2}, 0.04 \%(\mathrm{w} / \mathrm{v})$ digitonin. The reaction was started with $5 \mu \mathrm{l}$ of $20 \mathrm{mM}$ UDP-glucose containing $58,000 \mathrm{cpm}$ of UDP- $\left[{ }^{14} \mathrm{C}\right]$ glucose. After incubation at $25^{\circ} \mathrm{C}$ for $10 \mathrm{~min}$ the reaction was terminated by immersion in a boiling water bath for about $5 \mathrm{~min}$ and the $\left[{ }^{14} \mathrm{C}\right]$ glucan formed was measured by scintillation counting (Jiang et al., 2004).

\subsection{Determination of the Sucrose Synthase (SuSy) Activity}

Enzyme extraction and assay were according to King et al. (1997). Fiber cell samples (approximately $0.5 \mathrm{~g}$ fresh weight each) were ground into a fine powder in liquid nitrogen followed by grinding in cold $50 \mathrm{mM}$ Hepes- $\mathrm{NaOH}$ buffer $(\mathrm{pH} 7.5)(5: 1, \mathrm{v} / \mathrm{w})$ for $5 \mathrm{~min}$. The resulting homogenate was then filtered through four layers of cotton cloth and the filtrate was centrifuged at $11,000 \mathrm{~g}$ for $20 \mathrm{~min}$. All extraction procedures were carried out at $0-4^{\circ} \mathrm{C}$. Reaction mixtures contained $50 \mathrm{mM}$ Hepes- $\mathrm{NaOH}$ buffer ( $\mathrm{pH} 7.5), 10 \mathrm{mM} \mathrm{MgCl}, 14 \mathrm{mM}$ UDP-glucose, $50 \mathrm{mM}$ D-fructose and $0.1 \mathrm{ml}$ crude enzyme. The reactions were conducted at $37^{\circ} \mathrm{C}$ for $30 \mathrm{~min}$ and then were terminated by an addition of $0.1 \mathrm{ml} 2 \mathrm{M} \mathrm{NaOH}$ and kept at $100^{\circ} \mathrm{C}$ for $10 \mathrm{~min}$. After cooling, $3.5 \mathrm{ml} 30 \% \mathrm{HCl}$ and $1 \mathrm{ml} 1 \%$ resorcinol were added and 
incubated in an $80^{\circ} \mathrm{C}$ water bath for $10 \mathrm{~min}$. After being cooled, color development was measured at $480 \mathrm{~nm}$. The SuSy activity was expressed as milligram of sucrose per hour per gram fresh weight (FW) (fresh weight) (Tang, 1999).

\subsection{Cellulose Content Quantification}

To quantify cellulose content, about $1 \mathrm{~g}$ dry weight samples were hot extracted with Fibertec 1020 system (Foss Tecator AB). Briefly, samples were boiled wit $150 \mathrm{ml} 1.25 \% \mathrm{H}_{2} \mathrm{SO}_{4}$ for 30 min; then rinsed $3 \times$ with $100 \mathrm{ml}$ distilled water. The samples were further boiled with $150 \mathrm{ml}$ $1.25 \% \mathrm{NaOH}$ for $30 \mathrm{~min}$, then rinsed $3 \times$ with $100 \mathrm{ml}$ distilled water. The treated samples were dried in the oven at $130^{\circ} \mathrm{C}$ for $2 \mathrm{~h}$, and then weighed with a balance. The dry sample were transferred into a Muffle Furnace at $500^{\circ} \mathrm{C}$ for $4 \mathrm{~h}$, and then weighed again. The cellulose content was calculated as the percentage of the weight lost in each sample (the protocol was provided by the Foss Tecator Co. Ltd.).

\subsection{Determination of Fiber Orientational Distribution Angle $(\Psi)$}

The fiber orientational distribution angles were determined according to the method of Jiang (2006). The fiber X-ray diffraction was carried out by D8 DISCOVER (Bruker, Germany), the orientational angles were calculated by the accessory software, and the relation between the orientational separate angle ( $\alpha$ ), spiral angle $(\varphi)$ and orientational distribution angle ( $\psi$ use another symbol as this one usually means water potential) were calculated by the formula (1) and (2).

$$
\begin{aligned}
& 0.5 \times e^{\ln 2 \times\left(\frac{w_{1}}{\alpha}\right)^{2}}=\cos \left(h \times 2 \ln 2 \times\left(\frac{w_{1} \times \varphi}{\alpha}\right)^{2}\right) \\
& 0.4 \times e^{\ln 2 \times\left(\frac{w_{2}}{\alpha}\right)^{2}}=\cos \left(h \times 2 \ln 2 \times\left(\frac{w_{2} \times \varphi}{\alpha}\right)^{2}\right)
\end{aligned}
$$

\subsection{Fiber Strength Measurement}

Cotton fibers samples for strength measurement were excised from the bolls with a scalpel, air-dried and thoroughly mixed. The fiber strength $\left(\mathrm{cN}\right.$ tex $\left.{ }^{-1}\right)$ was determined by USTER ${ }^{\circ}$ HVI 1000 Classing (Uster Technologies Ltd, Switzerland) and measurements were repeated six times for each sample.

\subsection{Data Analysis}

Data were statistically analyzed with software SPSS or Microsoft Excel. These data were statistically analyzed by the shortest significant ranges (SSR) test at $P=0.05$ and/or $P=$ 0.01 .

\section{RESULTS AND DISCUSSION}

\subsection{Sucrose Synthase (SuSy) Activity}

SuSy activity in cotton fiber reached a peak at 35-40 DPA (Fig. 1). The importance/role of SuSy in cellulose accumulation for fiber strength has been documented (Amor et al., 1995; Delmar and Haigler, 2002), but our results relate this to the development period, as well as 
to temperature and position in the canopy. The time to peak activity of SuSy changed with the variations of both planting date (i.e. $T_{\text {DPA25-50) }}$ ) and boll position which has not been previously documented. At the same boll location, the effect of planting date ( $\left.T_{\mathrm{DPA} 25-50}\right)$ on the SuSy activity was large. When the $T_{D P A 25-50}$ was lower than $20.0^{\circ} \mathrm{C}$, the SuSy activity reached the highest level at about $40 \mathrm{DPA}$, which was 5 days later than that of about $26.0^{\circ} \mathrm{C}$, and it was the $T_{\text {DPA25-50 }}$ that mainly modified the SuSy activity. The higher the boll position, the lower the SuSy activity. When the $\mathrm{T}_{\mathrm{DPA} 25-50}$ was lower than $16.0^{\circ} \mathrm{C}$, boll position had little effect on SuSy activity. When $\mathrm{T}_{\mathrm{DPA} 25-50}$ was about $26.0^{\circ} \mathrm{C}$, the SuSy activity of the bolls in the $8^{\text {th }}$ PFB was higher than those in other PFB and $T_{\text {DPA25-50 }}$ conditions. This information further explains the pattern of cellulose accumulation and shows how this is influenced by planting date and boll position.
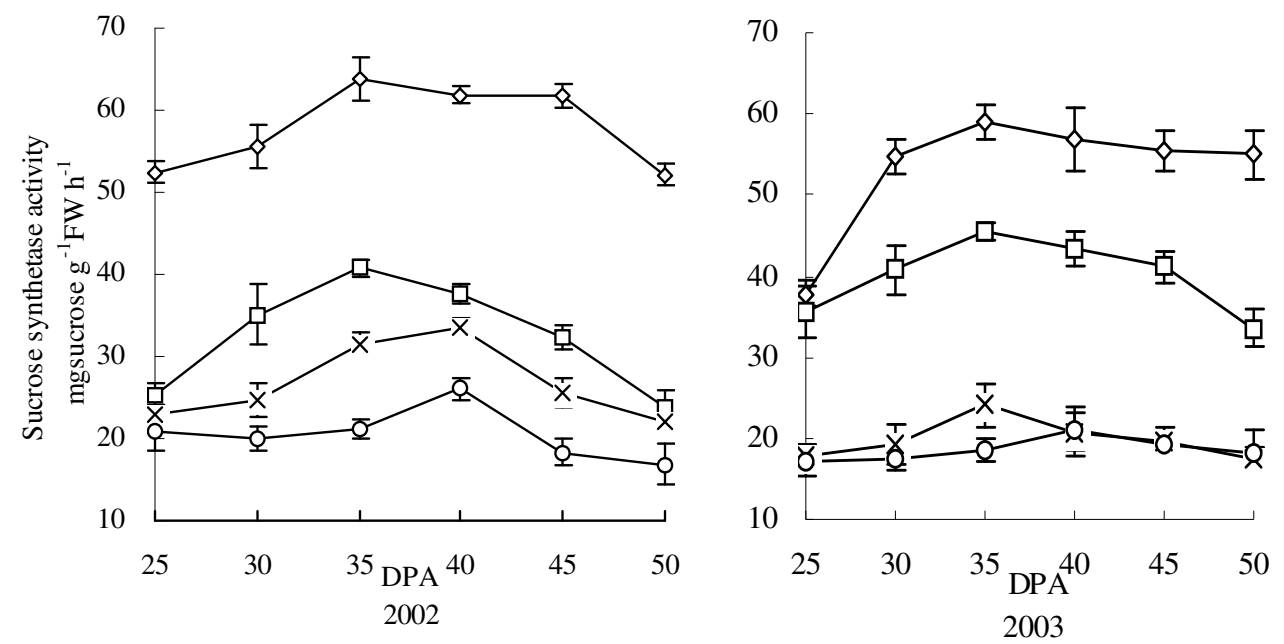

Fig. 1. The spatial and temporal changes of the activity of sucrose synthase in cotton fiber according to variations of planting date and boll position in 2002 and 2003

$\diamond$ and $\square$ stands for the $8^{\text {th }}$ and $12^{\text {th }}$ PFB in the planting date 20 April, respectively;

$x$ and $\circ$ stands for the $8^{\text {th }}$ and $12^{\text {th }}$ PFB in the planting date 20 June, respectively.

The error bars represent \pm S.E.

\section{2 $\beta$-1,3-Glucan Synthase Activity}

$\beta-1,3-g l u c a n$ (i.e. callose) synthase activity in cotton fiber was very sensitive to both $T_{\text {DPA25-50 }}$ and boll position, and was highest during the rapid thickening stage (i.e. 25-50 DPA ), which may delay the fiber cell secondary thickening for high consumption of UDP-glucose in callose synthesis (Fig. 2). The $\beta-1,3-$ glucan synthase activity decreased markedly with the increase in $T_{D P A 25-50}$. During fiber cell wall secondary modification, the $\beta$-1,3-glucan synthase activity was obviously affected by boll position when the $\mathrm{T}_{\mathrm{DPA} 25-50}$ was between $22.0-26.0^{\circ} \mathrm{C}$, but it changed little with boll position when the $\mathrm{T}_{\mathrm{DPA} 25-50}$ was about $20.0^{\circ} \mathrm{C}$. The higher the PFB, the higher the $\beta-1,3-g l u c a n$ synthase activity. This suggested that boll position plays an important role in determining the $\beta-1,3-$ glucan synthase activity in the planting date of 20 April in addition to $T_{D P A 25-50}$ which always functions as the decisive factor in regulating the $\beta$ 1,3 -glucan synthase activity. However, in the $8^{\text {th }}$ PFB and $12^{\text {th }}$ PFB of the late planting date (20 June) (when $\mathrm{T}_{\mathrm{DPA} 25-50}$ was lower than $16.0^{\circ} \mathrm{C}$ ), the effect of boll position was not significant. Our findings support those of Scheible and Pauly (2004) of the involvement of callose synthase activity in secondary wall cellulose synthesis, but add information of the 
effect of environment (temperature due to planting date) and position of the boll and developing fiber in the cotton canopy.
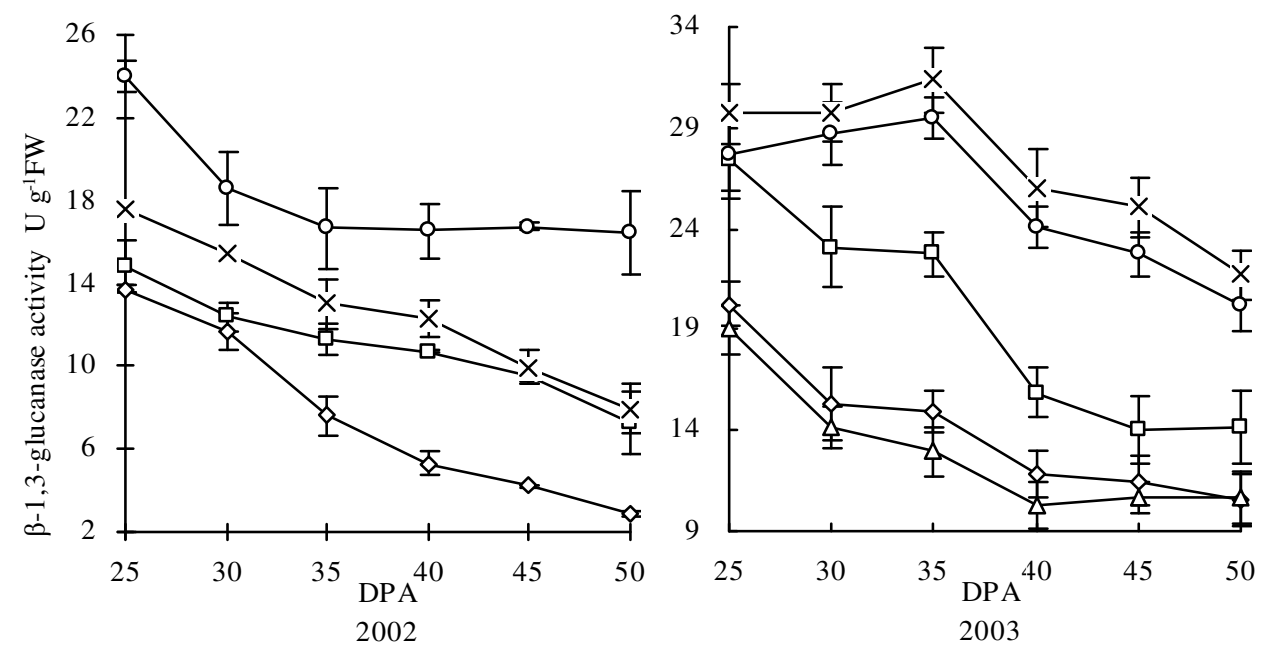

Fig. 2. The spatial and temporal changes of the activity of $\beta-1,3-$ glucan synthase in cotton fiber according to variations of planting date and boll position in 2002 and 2003 $\checkmark$ and $\square$ stands for the $8^{\text {th }}$ and $12^{\text {th }}$ PFB in the planting date of 20 April, respectively; $\Delta, x$ and $\circ$ stand for the $2^{\text {th }}, 8^{\text {th }}$ and $12^{\text {th }}$ PFB in the planting date of 20 June, respectively. The error bars represent \pm S.E.

\subsection{Fiber Cellulose Content}

The two years data both showed that the highest synthesis rate of the cellulose was occurred at 25-30 DPA (Fig. 3). The temperature during that stage ( $\left.T_{\text {DPA25-50 }}\right)$ also notably influenced the cellulose synthesis; the lower the $\mathrm{T}_{\mathrm{DPA} 25-50}$, the slower the cellulose synthesis. In the same PFB, the cellulose content changed little when the $T_{D P A 25-50}$ was about $26.0^{\circ} \mathrm{C}$ compare to that of the $\mathrm{T}_{\mathrm{DPA} 25-50}$ which was lower than $20.0^{\circ} \mathrm{C}$. This showed that, during the cotton fiber developing process, $T_{\text {DPA25-50 }}$ was always the important factor that influenced the cellulose synthesis rate and the dynamics of cellulose content. Similarly, just like the effect of boll position and $T_{\mathrm{DPA} 25-50}$ on the activity of SuSy and $\beta-1,3-$ glucan (i.e., callose) synthase when $T_{D P A 25-50}$ was $20.0-26.0^{\circ} \mathrm{C}$, boll position and $T_{D P A 25-50}$ affected the cellulose synthesis, but when the $\mathrm{T}_{\text {DPA25-50 }}$ was lower than $20.0^{\circ} \mathrm{C}$, it was the $\mathrm{T}_{\text {DPA25-50 }}$ that played a dominant role in deciding the cellulose synthesis rate. Planting date is known to affect cotton development (Ali et al., 2009), but there is limited information on the specific effects. Wang et al. (2008) had suggested that low temperature in late sowing dates resulted in a decrease in cotton fiber strength by the down-regulation of cellulose accumulation rate and key enzymes activities. Our study shows how the differences in the activities of the key enzymes in relation to temperature and boll position during the secondary wall thickening affects cellulose deposition and fiber strength. 

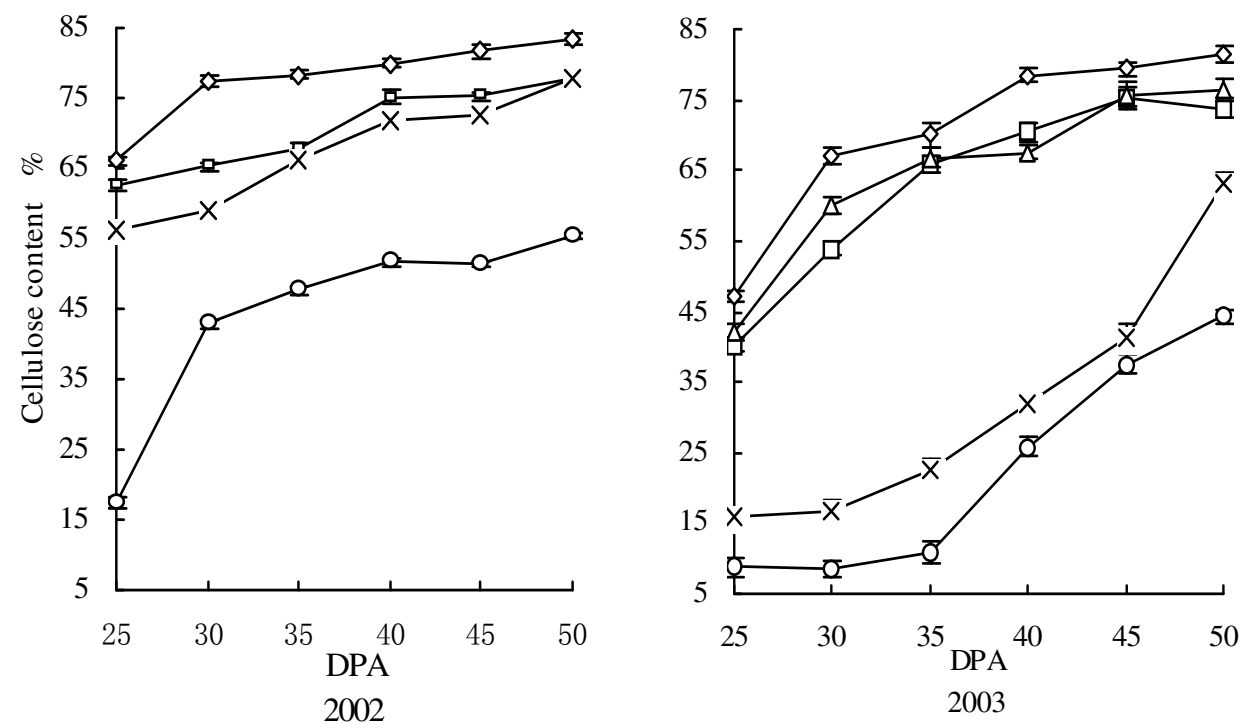

Fig. 3. The spatial and temporal changes of cellulose content in cotton fiber according to variations of planting date and boll position in 2002 and 2003

$\checkmark$ and $\square$ stands for the 8th and 12th PFB in the planting date of 20 April, respectively; $\Delta, x$ and $\circ$ stands for the $2^{\text {nd }}$, 8th and 12th PFB in the planting date of 20 June, respectively. The error bars represent \pm S.E.

\subsection{The Orientational Parameter of the Fiber Super-Molecular Structure}

The orientational parameters of the fiber sampled from the early planting date (20 April) were all significantly lower than that of the late planting date (20 June) (Fig. 4). As bolls that were located in the I-12 and II-2 nodal fruiting positions were developed in the same $\mathrm{T}_{\text {DPA25-50, }}$, the significant difference of the angles between them strongly indicated that boll position also has a great influence on orientational parameters of the fiber. The slight variation in the orientational parameter in the $8^{\text {th }}$ PFB and $12^{\text {th }}$ PFB of the late planting date (where $T_{\text {DPA25-50 }}$ was lower than $16.0^{\circ} \mathrm{C}$ ) indicated that boll position did not play an important role in regulating the orientational parameter in this situation.

Fiber strength is strongly related to microfibrils distribution and orientation (Liu et al., 1996), and there have been a number of studies about fiber structure as defined by three angles: orientational separate angle $(\alpha)$, spiral angle $(\varphi)$ and orientational distribution angle $(\psi)$ (Liu et al., 1996; Zhao et al., 2005). Our study shows the influence of boll position on these parameters.

\subsection{Fiber Strength}

There was a significant difference of fiber strength between the fiber of I-12 and II-2 (Fig. 5). As bolls that were located in the I-12 and II-2 positions were developed in the same T (Table 1), this showed that boll position had a great effect on fiber strength formation. Furthermore, fiber strength was obviously affected by planting date and declined with the decreased $\mathrm{T}_{\mathrm{DPA} 25-50}$. 

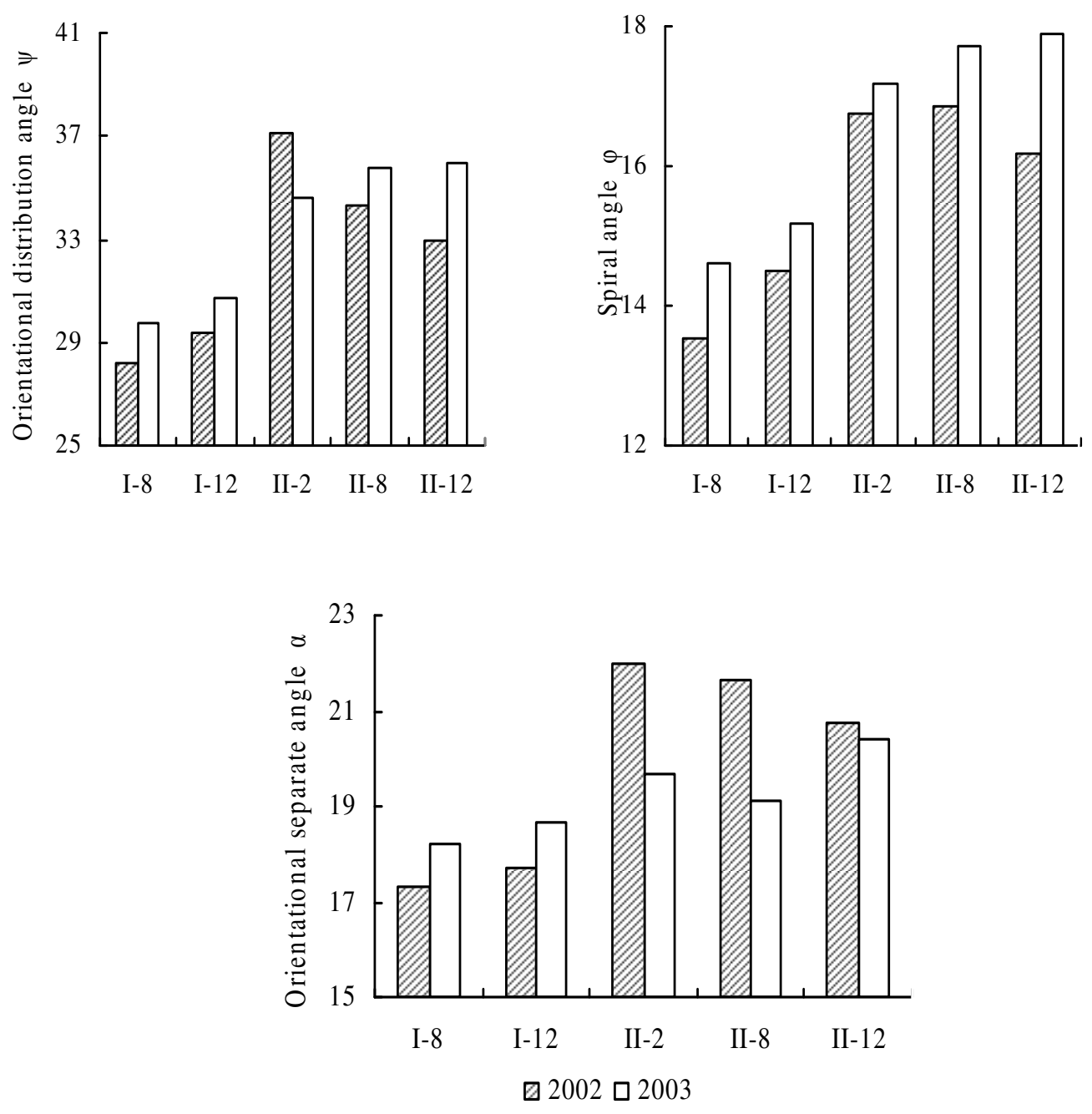

Fig. 4. Effect of planting date and boll position on the orientational distribution angle, spiral angle and orientational separate angle of cotton fiber in 2002 and 2003

I-8 and I-12 stands for the $8^{\text {th }}$ and $12^{\text {th }}$ PFB in the planting date of 20 April, respectively; II-2, II-8 and II-12 stands for $2^{\text {nd }}, 8^{\text {th }}$ and $12^{\text {th }}$ PFB in the planting date of 20 June, respectively.

With the decrease of the $T_{D P A 25-50}$, the impact of boll position on fiber strength diminished. When the $\mathrm{T}_{\mathrm{DPA} 25-50}$ was $22.0-26.0^{\circ} \mathrm{C}$, the difference of fiber strength between the middle position of the fruiting branch ( $8^{\text {th }}$ PFB) and the top position of fruiting branch (12 $2^{\text {th }}$ PFB) was higher than that of $\mathrm{T}_{\mathrm{DPA} 25-50}$ with lower than $20.0^{\circ} \mathrm{C}$ (Fig. 5). This showed that in the normal planting date, the fiber strength was much more susceptible to the variation of boll position, and both $\mathrm{T}_{\mathrm{DPA} 25-50}$ and boll position were important for fiber strength determination. 

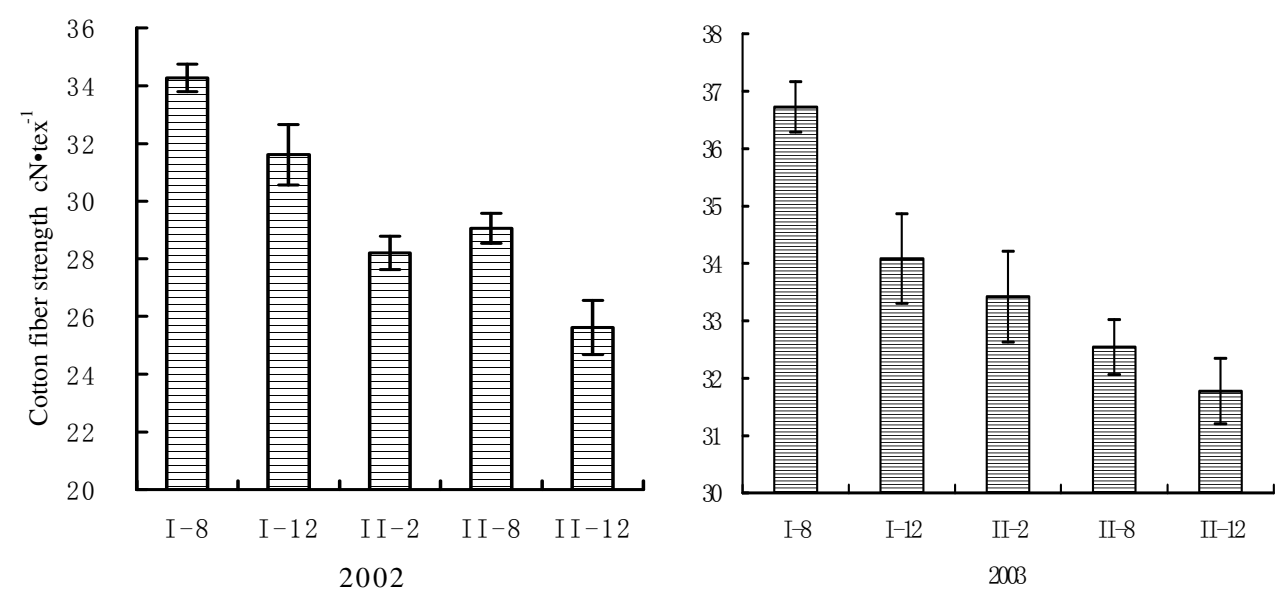

Fig. 5. Effect of planting date and boll position of cotton plants on fiber strength in 2002 and 2003

I-8 and I-12 stands for the $8^{\text {th }}$ and $12^{\text {th }}$ PFB in the planting date of 20 April, respectively; II-2, II-8 and II-12 stands for $2^{\text {nd }}$, $8^{\text {th }}$ and $12^{\text {th }}$ PFB in the planting date of 20 June, respectively. The error bars represent \pm S.E.

\section{CONCLUSIONS}

This research showed that the cotton fiber cell thickening process was greatly affected by both planting date and boll position. Thus, research that only focuses on the impact of the planting date or boll position individually on fiber strength development is unreliable. The results also showed that there existed an interactive effect between planting date and boll position on regulating fiber strength formation. In different planting dates, variation in the same boll position caused different degrees of effects on the key enzyme activities and fiber strength.

Evidence showed that the key enzymes activity (SuSy and $\beta-1,3$-glucan synthase) of fiber development during the fiber cell wall thickening process were significantly different at different boll position in the same planting date, and similarly, they were significantly different in different planting dates at the same boll position. This might be an important cause leading to the recorded difference between the cellulose synthesis and the cellulose content. There existed an optimum planting date and boll position for the highest fiber strength formation, and the optimum planting date or boll position cannot operate separately as they have an interactive effect. The optimum condition for the development of fiber cell wall thickening and the formation of fiber strength may be the $8^{\text {th }}$ PFB with the $T_{\text {DPA25-50 }}$ of about $26.0^{\circ} \mathrm{C}$.

When the $T_{D P A 25-50}$ was about $26.0^{\circ} \mathrm{C}$, the SuSy activity of cotton fiber was high and the $\beta$ 1,3-glucan synthase activity was low, this were related to the cellulose synthesis which subsequently led to a low value of the orientation parameter of fiber super-molecular structure and a high fiber strength.

Fiber strength was significantly influenced by boll location when the $T_{D P A 25-50}$ was higher than $20.0^{\circ} \mathrm{C}$, such that the fiber strength in the bottom $\left(2^{\text {nd }} \mathrm{PFB}\right)$ and middle $\left(8^{\text {th }} \mathrm{PFB}\right)$ positions of cotton plants were significantly higher than that from the top positions $\left(12^{\text {th }}\right.$ PFB). The 
minimum temperature of the $\mathrm{T}_{\mathrm{DPA} 25-50}$ for the cellulose synthesis appeared to be about $16.0^{\circ} \mathrm{C}$. When the $\mathrm{T}_{\mathrm{DPA} 25-50}$ was lower than $16.0^{\circ} \mathrm{C}$, the activity of key enzymes was maintained at a constant level and with little change with variation of planting date and boll position.

\section{ACKNOWLEGEMENTS}

This work was granted by the National Natural Science Foundation of China (Grant No. 30771279, 30971735).

\section{REFERENCES}

Ali, H., et al. (2009). Effect of sowing dates and plant spacing on growth and dry matter partitioning in cotton (Gossypium hirsutum L.). Pak. J. Bot., 41, 2145-2155.

Amor, Y. et al. (1995). A membrane-associated form of sucrose synthase and its potential role in synthesis of cellulose and callose in plants. Proc. Natl. Acad. Sci. U S A., 92, 9353-9357.

Bernhardt, J.L., Phillips, J.R. (1986). Fruiting position influence on yield component of cotton bolls. Proc. Beltwide Cotton Conf. National Cotton Council of America. Memphis., TN. pp. 113-115.

Brown, R.M. Jr., et al. (1996). Cellulose biosynthesis in higher plants. Trends Plant Sci., 5,149-155.

Davidonis, G.H., et al. (2004). Cotton fiber quality is related to boll location and planting date. Agron. J., 96, 42-47.

Delmer, D.P. (1999). Cellulose biosynthesis: exciting times for a difficult field of study. Annu. Rev. Plant Phys., 50, 245-276.

Delmer, D.P., Haigler, C.H. (2002). The regulation of metabolic flux to cellulose, a major sink for carbon in plants. Metab. Eng., 4, $22-28$.

Jiang G.H., et al. (2006). Effects of low temperature on physiological mechanisms of cotton fiber strength forming process. Journal of Plant Ecology, 30, 335- 343 (in Chinese with English abstract).

Haigler, C.H., et al. (2001). Carbon Partitioning to Cellulose Synthesis. Plant Mol. Biol., 47, 29-51.

Kim, H.J., Triplett, B.A. (2001). Cotton fiber growth in planta and in vitro. models for plant cell elongation and cell wall biogenesis. Plant Physiol., 127, 1361-1366.

King, S.P. et al. (1997). Carbohydrate content and enzyme metabolize in developing canola siliques. Plant Physiol., 114, 153-160.

Liu, J.H., et al. (1996). Effects of anthesis date on the dynamic change of cotton fiber supermolecular structure and strength. Scientia Agricultura Sinica, 29, 59-65 (in Chinese with English abstract).

MacDonald, S., Vollrath, T. (2005). The forces of shaping world cotton consumption after the multifiber arrangement. Outlook Report CWS-05c-01. USDA, Economic Research Service.

Meredith, W.R. (2005). Minimum number of genes controlling cotton fiber strength in a backcross population. Crop Sci., 45, 1114-1119.

Salnikov, V.V., et al. (2003). Localization of sucrose synthase and callose in freezesubsituted secondary wall-stage cotton fibers. Protoplasma., 221, 175-184.

Saxena, I.M., Brown, R.M. (2000). Cellulose synthases and related enzyme. Curr. Opin. Plant Biol., 3, 523-531. 
Scheible, W.R., Pauly, M. (2004). Glycosyltransferases and cell wall biosynthesis: novel players and insights. Curr. Opin. Plant Biol., 7, 285-295.

Sequeira, R.A., et al. (1994). Inclusion of plant structure and fiber quality into a distributed delay cotton model to improve management and optimize profit. Ecol. Model., 71, $161-186$.

Tang, Z.C. (1999). A guidebook to modern experiment about plant physiology, pp. 126. Shanghai: The Science press (in Chinese).

Ruan, Y.L., et al. (1997). The differential expression of sucrose synthase in relation to diverse patterns of carbon portioning in developing cotton seed. Plant Physiol., 115, 375-385.

Ruan, Y.L., Chourey, P.S. (1998). A fiberless seed mutation in cotton is associated with lack of fiber cell initiation in ovule epidermis and alterations in sucrose synthase expression and carbon partitioning in developing seeds. Plant Physiol., 118, 399-406.

Ruan, Y.L., et al. (2003). Suppression of sucrose synthase gene expression.

Wang, Y.H., et al. (2009). The rate of cellulose increase is highly related to cotton fibre strength and is significantly determined by its genetic background and boll period temperature. Plant Growth Regul., 57, 203-209.

Zhao, R.H., et al. (2005). Super-molecular structure and its relation to quality parameters in cotton fiber. Cotton Sci., 17, 112-116 (in Chinese with English abstract).

(c) 2011 Zhou et al; This is an Open Access article distributed under the terms of the Creative Commons Attribution License (http://creativecommons.org/licenses/by/3.0), which permits unrestricted use, distribution, and reproduction in any medium, provided the original work is properly cited. 